\title{
REVISED Unexpected results in Chernozem soil respiration while measuring the effect of a bio-fertilizer on soil microbial
}

\section{activity [version 2; peer review: 2 approved]}

\author{
Gabriela Bautista (iD1,2, Bence Mátyás (D2,3, Isabel Carpio², Richard Vilches³, \\ Karina Pazmino 4,5 \\ ${ }^{1}$ Department of Agricultural Chemistry and Soil Sciences, University of Debrecen, Debrecen, Hungary \\ ${ }^{2}$ Grupo de Investigación Mentoria y Gestión del Cambio, Universidad Politécnica Salesiana, Cuenca, Ecuador \\ ${ }^{3}$ Grupo de Investigación en Ciencias Ambientales, Universidad Politécnica Salesiana, Quito, Ecuador \\ ${ }^{4}$ Ingeneria Ambiental, Universidad Politécnica Salesiana, Quito, Ecuador \\ ${ }^{5}$ Grupo de Innovación Educativa UPS en Ciencas Básicas, Universidad Politécnica Salesiana, Quito, Ecuador
}

V2 First published: 03 Nov 2017, 6:1950

https://doi.org/10.12688/f1000research.12936.1

Latest published: 18 Dec 2017, 6:1950

https://doi.org/10.12688/f1000research.12936.2

\section{Abstract}

The number of studies investigating the effect of bio-fertilizers is increasing because of their importance in sustainable agriculture and environmental quality. In our experiments, we measured the effect of different fertilizers on soil respiration. In the present study, we were looking for the cause of unexpected changes in $\mathrm{CO} 2$ values while examining Chernozem soil samples. We concluded that $\mathrm{CO} 2$ oxidizing microbes or methanotrophs may be present in the soil that periodically consume $\mathrm{CO} 2$. This is unusual for a sample taken from the upper layer of well-ventilated Chernozem soil with optimal moisture content.

Keywords

bio-fertilizer, soil respiration, Chernozem, OxiTop

\section{Open Peer Review \\ Approval Status \\ 1 \\ 2 \\ version 2 \\ (revision) \\ 18 Dec 2017 \\ version 1 \\ 03 Nov 2017

$\checkmark$
view

1. Ankit Singla, Regional Centre of Organic Farming, Bhubaneswar, India

2. Muhammad Aslam Ali, Bangladesh

Agricultural University, Mymensingh, Bangladesh

Any reports and responses or comments on the article can be found at the end of the article. 
Corresponding author: Gabriela Bautista (gebautista89@gmail.com)

Author roles: Bautista G: Investigation, Methodology, Writing - Original Draft Preparation, Writing - Review \& Editing; Mátyás B: Investigation, Methodology, Writing - Original Draft Preparation, Writing - Review \& Editing; Carpio I: Methodology, Project Administration, Writing - Review \& Editing; Vilches R: Investigation, Methodology, Writing - Review \& Editing; Pazmino K: Investigation, Methodology, Project Administration, Writing - Review \& Editing

Competing interests: No competing interests were disclosed.

Grant information: The author(s) declared that no grants were involved in supporting this work.

Copyright: $\odot 2017$ Bautista $\mathrm{G}$ et al. This is an open access article distributed under the terms of the Creative Commons Attribution License, which permits unrestricted use, distribution, and reproduction in any medium, provided the original work is properly cited. Data associated with the article are available under the terms of the Creative Commons Zero "No rights reserved" data waiver (CC0 1.0 Public domain dedication).

How to cite this article: Bautista G, Mátyás B, Carpio I et al. Unexpected results in Chernozem soil respiration while measuring the effect of a bio-fertilizer on soil microbial activity [version 2; peer review: 2 approved] F1000Research 2017, 6:1950

https://doi.org/10.12688/f1000research.12936.2

First published: 03 Nov 2017, 6:1950 https://doi.org/10.12688/f1000research.12936.1 


\section{REVISED Amendments from Version 1}

We extended the Introduction chapter to clarify the importance of measuring physical and chemical soil properties when examining soil microbiological activities.

We extended the Methods chapter and named the methods and required sample preparations that were applied for measuring the main soil properties.

Dataset 1 was replaced with Table 1 in the main text. This was also updated with a new parameter, Total Nitrogen, according to Prof. Muhammad Aslam Ali's advice.

We responded by comments to Prof. Muhammad Aslam Ali's questions related to the experimental setups, and marks of the figures.

We named 3 more co-authors who strongly contributed to the measurements of the physical and chemical soil properties.

See referee reports

\section{Introduction}

The soil can be characterized by physical, chemical and microbiological properties ${ }^{1-4}$. The quantitative (microbial biomass, number of bacteria) $)^{5,6}$ and qualitative (enzymatic activity, soil respiration $)^{7,8}$ microbiological properties of the soil greatly contribute to the impact analysis of land use $\mathrm{e}^{9-11}$, nutrition ${ }^{12}$ and soil management ${ }^{13}$. Research related to the benefits of microbes as biofertilizer has become increasingly important in the agricultural sector. This is due to the possibility of achieving higher crop yields while minimizing negative impact on the environment. It is well known that bio-fertilizers increase plant yield and improve soil fertility ${ }^{14-16}$. Soil respiration is an important indicator of soil microbial activity ${ }^{17,18}$. In our experiments, we measured the effect of different chemicals ${ }^{19-22}$ and a bio-fertilizer on soil microbial activity, using both well-established and novel methods under laboratory conditions. We present some unexpected results from a setup in which Chernozem soil samples were examined.

\section{Methods}

\section{Sampling site}

A total of 24 soil samples were collected near Debrecen, Hungary, on the 19th April 2016, from an upper layer $(0-20 \mathrm{~cm})$ of

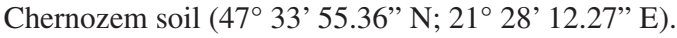

\section{Treatment}

The phylazonit bio-fertilizer (produced by Phylazonit.Ltd, Hungary) with the following composition: Bacillus megaterium, Bacillus circulans, Pseudomonas putida, was tested (15 l/ha) in an optimized ratio for soil injection. Number of bacteria: $10^{9}$ piecel $\mathrm{cm}^{3}$.

\section{Soil properties}

Soil moisture content was determined gravimetrically, drying the soil at $105^{\circ} \mathrm{C}$ for 24 hours according to Klimes-Szmik's method $(1970)^{23}$. Silt and clay fractions were measured by the settling method $^{24}$. We measured the Arany-type plasticity index according to Stefanovits $(1975)^{25-27}$, while the minimal water capacity and soil texture were determined by Klimes-Szmik's method ${ }^{23}$. To measure the chemical properties of the soil, the samples were sieved through $2 \mathrm{~mm}$ mesh and pre-incubated at $25^{\circ} \mathrm{C}$ for 72 hours. Soil $\mathrm{pH}$ in distilled water and in $1 \mathrm{M}$ potassium chloride $\mathrm{KCl}$ (soil/ water, $1 / 2.5$, w/w) were determined according to Buzás $(1988)^{24}$. The electrical conductivity (EC) (soil/water, 1/5, w/w) was then determined with a glass electrode according to Kong et al, $2013^{28}$. The hydrolytic acidity (y1) was measured according to Buzás $(1988)^{24}$, while the concentration of $\mathrm{NO}_{3}^{-}-\mathrm{N}$ was determined according to Felföldy $(1987)^{29}$. Total nitrogen was determined according to Kong et al. $(2013)^{28}$. Nitrate exploration was carried out after 14 days incubation according to Felföldy $(1987)^{29}$. We determined AL- $\mathrm{P}_{2} \mathrm{O}_{5}$ and $\mathrm{ALK}_{2} \mathrm{O}$ based on Szegi's method $(1979)^{30}$. The humus content was determined using potassium dichromate according to Székely $(1988)^{31}$. Total number of bacteria was counted in bouillon agar using the plate dilution method (Szegi, 1979) ${ }^{30}$. We measured the organic carbon concentration in $\mathrm{K}_{2} \mathrm{SO}_{4}$ extract, following the protocol in Székely et al. $(1988)^{31}$. Microbial biomass carbon (MBC) was measured using the chloroform fumigation-extraction method. Soil samples were fumigated by adding alcohol-free chloroform at $25^{\circ} \mathrm{C}$ for 24 hours. The fumigated and unfumigated soil samples were extracted with $50 \mathrm{ml} 0.5 \mathrm{M}$ potassium sulfate $\left(\mathrm{K}_{2} \mathrm{SO}_{4}\right)$ according to Vance et al. $(1987)^{32}$. The following formula was applied to calculate the MBC (Kong et al., 2013) ${ }^{28}$ :

$$
\mathrm{MBC}=2.22 \times \mathrm{EC}
$$

where $\mathrm{EC}=$ organic $\mathrm{C}$ extracted from fumigated soils - organic $\mathrm{C}$ extracted from unfumigated soils (Table 1).

\section{Soil respiration}

The experimental design was completely randomized, treatments were incubations $\left(25^{\circ} \mathrm{C}\right)$. An OxiTop OC110 respirometer was used to quantify the release and capture of $\mathrm{CO}_{2}$ that is automatically determined by the device after the biological oxygen demand (BOD) required for the degradation of organic matter has been measured. We used a $500 \mathrm{ml}$ glass bottle system following the instruction manual (https://www.wtw.com/en/service/downloads/ operating-manuals.html). $10 \mathrm{~g}$ of soil sample were placed into OxiTop flasks, and capped with the sensor heads according to Barrales-Brito et al. (2014) $)^{33}$. 2.5g of $\mathrm{CO}_{2}$ absorber (sodalime) were then added to a tank to absorb the generated $\mathrm{CO}_{2}{ }^{33}$. An induced method was also used, in which $0.1 \mathrm{~g}$ glucose was added to the soil samples. Each treatment was replicated four times. As Figure 1 shows, four samples were always measured in parallel: Absolute control (does not contain fertilizer, nor added glucose), Induced control (contains added glucose), Treated (contains bio-fertilizer) and Induced treated (contains bio-fertilizer and glucose). The Oxitop automatically provides the values related to $\mathrm{CO}_{2}$ production according to the pressure change measured by its sensor (there is no need to carry out titrations or any additional work). 


\begin{tabular}{|c|c|c|c|}
\hline Soil property & Value & Unit & Protocol \\
\hline $\begin{array}{l}\text { Silt and clay } \\
\text { fraction }\end{array}$ & 37.48 & $\%$ & $\begin{array}{l}\text { Buzásl. (1988): Manual of Soil and Agrochemical } \\
\text { Analysis Vol.1. (in Hungarian). INDA } 4231 \\
\text { Kiadó. Budapest. }\end{array}$ \\
\hline Hygroscopicity & 2.23 & hy & $\begin{array}{l}\text { Buzásl. (1988): Manual of Soil and Agrochemical } \\
\text { Analysis Vol.1. (in Hungarian). INDA } 4231 \\
\text { Kiadó. Budapest. }\end{array}$ \\
\hline $\begin{array}{l}\text { Arany-type of } \\
\text { plasticity limit }\end{array}$ & 39 & $\mathrm{KA}$ & Szegi \\
\hline Moisture content & $19-21$ & $\%$ & Szegi \\
\hline Hydrolytic acidity & 5.94 & $\mathrm{y} 1$ & $\begin{array}{l}\text { Buzásl. (1988): Manual of Soil and Agrochemical } \\
\text { Analysis Vol.1. (in Hungarian). INDA } 4231 \\
\text { Kiadó. Budapest. }\end{array}$ \\
\hline organic-C & 1.4 & $\%$ & Székely \\
\hline Nitrate-N & 7.4 & $\mathrm{mg} / \mathrm{kg}$ & $\begin{array}{l}\text { Hayashi A, Sakamoto K, Yoshida T 1997: A rapid } \\
\text { method for determination of nitrate in soil by } \\
\text { hydrazine reduction produce. Jpn. J. Soil Sci. Plant } \\
\text { Nutr.,68, } 322\end{array}$ \\
\hline Total-N & 2.6 & mg g-1 D.S & \\
\hline AL-soluble P & 48.6 & P2O5 mg/kg & Szegi \\
\hline AL-soluble $\mathrm{K}$ & 222 & $\mathrm{~K} 2 \mathrm{O}$ mg/kg & Szegi \\
\hline $\mathrm{pH}(\mathrm{H} 2 \mathrm{O})$ & 6.8 & $\mathrm{pH}$ & $\begin{array}{l}\text { BuzásI. (1988): Manual of Soil and Agrochemical } \\
\text { Analysis Vol.1. (in Hungarian). INDA } 4231 \\
\text { Kiadó. Budapest. }\end{array}$ \\
\hline $\mathrm{pH}(\mathrm{KCl})$ & 6.1 & $\mathrm{pH}$ & $\begin{array}{l}\text { Buzásl. (1988): Manual of Soil and Agrochemical } \\
\text { Analysis Vol.1. (in Hungarian). INDA } 4231 \\
\text { Kiadó. Budapest. }\end{array}$ \\
\hline Topsoil & $80-90$ & $\mathrm{~cm}$ & Szegi \\
\hline Soil texture & Loam & & $\begin{array}{l}\text { BuzásI. (1988): Manual of Soil and Agrochemical } \\
\text { Analysis Vol.1. (in Hungarian). INDA } 4231 \\
\text { Kiadó. Budapest. }\end{array}$ \\
\hline $\begin{array}{l}\text { Minimal water } \\
\text { capacity }\end{array}$ & 26.22 & VKmin & Szegi \\
\hline Humus content & 2.81 & $\%$ & $\begin{array}{l}\text { Buzásl. (1988): Manual of Soil and Agrochemical } \\
\text { Analysis Vol.1. (in Hungarian). INDA } 4231 \\
\text { Kiadó. Budapest. }\end{array}$ \\
\hline $\begin{array}{l}\text { Total number of } \\
\text { bacteria }\end{array}$ & 9.59 & $\begin{array}{l}1.000 .000 \\
\text { colony/g }\end{array}$ & Szegi \\
\hline Nitrate exploration & 34.28 & $\mathrm{mg} / \mathrm{kg}$ & Felföldy \\
\hline $\begin{array}{l}\text { Microbial biomass } \\
\text { carbon }\end{array}$ & 333 & $\mathrm{mg} / \mathrm{kg}$ & $\begin{array}{l}\text { Vance ED, Brookes PC, Jenkinson DS 1987: An } \\
\text { extraction method for measuring soil microbial } \\
\text { biomass-C. Soil Biol. Biochem.,19, 703-707. }\end{array}$ \\
\hline
\end{tabular}

\section{Results}

The treated samples produced more $\mathrm{CO}_{2}$ than the controls, as expected (Dataset 1). Each repeat with the exception of one showed increasing $\mathrm{CO}_{2}$ values (Figure 1), as the pressure continuously decreased in the bottle due to gas (oxygen) consumption. One sample produced unexpected results (Figure 2). In the first 12 hours, the treated samples produced more $\mathrm{CO}_{2}$ than the controls in each measurement. Following this, a fluctuation in the values was observed.
Dataset 1. Average values of produced $\mathrm{CO} 2(\mathrm{ml} / \mathrm{l})$ with different treatments 'Control' does not contain fertilizer, nor added glucose. 'Control+Glucose' contains $0,1 \mathrm{~g}$ of added glucose. 'Biofertilizer' contains Phylazonit biofertilizer. 'Biofertilizer+Glucose' contains Phylazonit biofertilizer and 0,1 $\mathrm{g}$ of added glucose

http://dx.doi.org/10.5256/f1000research.12936.d182663. 


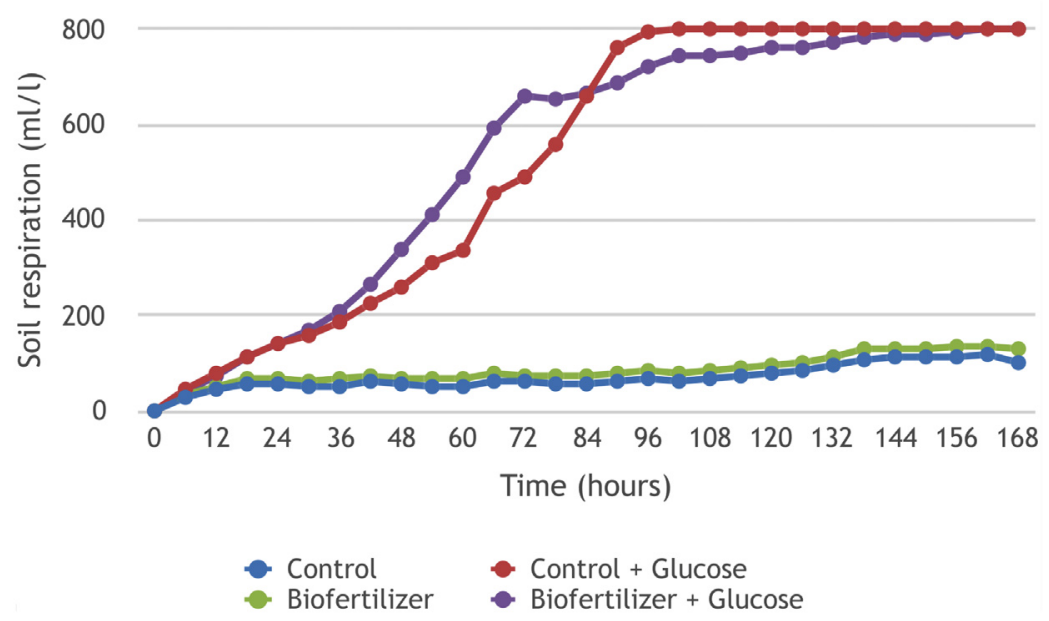

Figure 1. Differences in $\mathbf{C O}_{2}$ production of treated and control soil samples. The induced method was carried out so that the difference between the results of control and the treated soil samples could become detectable sooner. Glucose was applied as inducer. As expected the $\mathrm{CO}_{2}$ values increase or stagnate.

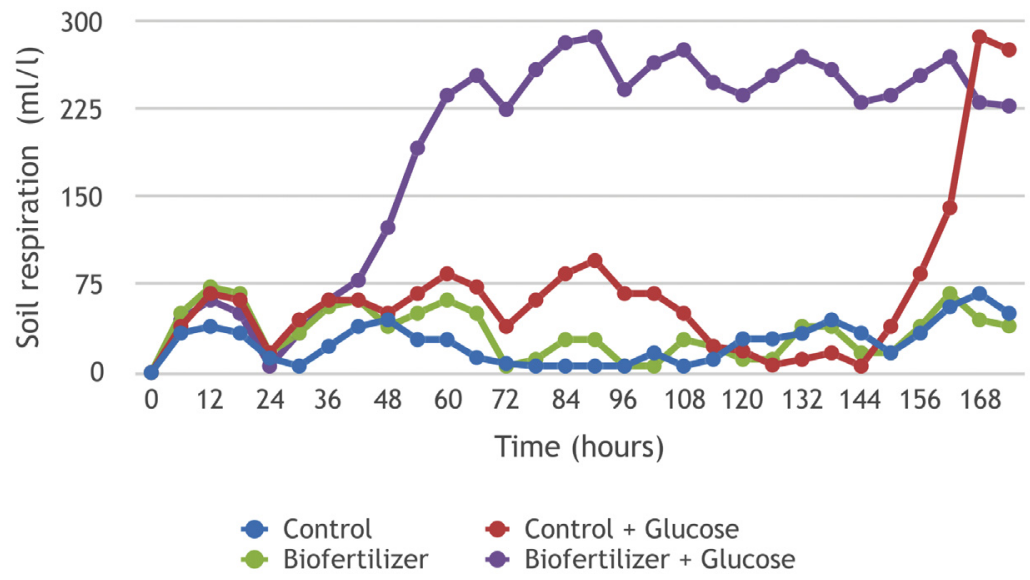

Figure 2. This sample shows $\mathrm{CO}_{2}$ values periodically decreasing in all conditions. After examining the Oxitop device's operation, this pattern became more interesting to us, as the device quantifies $\mathrm{CO}_{2}$ production by measuring $\mathrm{BOD}$ required for the degradation of organic matter. From the decreasing $\mathrm{CO}_{2}$ values, we conclude that there was oxygen production and/or $\mathrm{CO}_{2}$ consumption in the Oxitop bottles.

Dataset 2. Comparison of produced $\mathrm{CO} 2(\mathrm{ml} / \mathrm{l})$ in the sample in which unexpected (periodically decreasing $\mathrm{CO} 2$ ) values can be observed. 'Control' does not contain fertilizer, nor added glucose. 'Control+Glucose' contains $0,1 \mathrm{~g}$ of added glucose. 'Biofertilizer' contains Phylazonit bio-fertilizer. 'Biofertilizer+Glucose' contains Phylazonit bio-fertilizer and $0,1 \mathrm{~g}$ of added glucose

http://dx.doi.org/10.5256/f1000research.12936.d182664

\section{Discussion}

In a closed system where the pressure decreases due to oxygen consumption, the values of $\mathrm{CO} 2$ production must increase or stagnate with the passage of time, but this was not the case with one of the samples (Figure 2). Here, a decrease in $\mathrm{CO}_{2}$ occurred (Dataset 2). The following possible explanations were excluded:

- Presence of algae: there was no light in the incubator, so there was no photosynthesis.

- Changing pressure caused by changing temperature: the temperature was constant in the setup.

- Absorption by the water in the sample: all other samples that produced increasing amount of $\mathrm{CO}_{2}$ had the same or comparable moisture content.

One reason that seemed more likely was that $\mathrm{CO}_{2}$ oxidizing microbes or methanotrophs may have been present in the soil, 
using the produced $\mathrm{CO}_{2}$ periodically. This is unusual, since most of the studies report the presence of these bacteria in seawater ${ }^{34}$, paddy fields $s^{35}$ or industrial processes ${ }^{36}$ and not in well-ventilated Chernozem soil. Further genomics research could detect the bacterial strains that consumed the $\mathrm{CO}_{2}$ in this soil.

\section{Data availability}

Dataset 1: Average values of produced $\mathrm{CO}_{2}(\mathrm{ml} / \mathrm{l})$ with different treatments. 'Control' does not contain fertilizer, nor added glucose. 'Control+Glucose' contains $0,1 \mathrm{~g}$ of added glucose. 'Biofertilizer' contains Phylazonit bio-fertilizer. 'Biofertilizer+Glucose' contains Phylazonit bio-fertilizer and 0,1 g of added glucose. DOI, 10.5256/ f1000research.12936.d182663 ${ }^{37}$.

Dataset 2: Comparison of produced $\mathrm{CO}_{2}(\mathrm{ml} / \mathrm{l})$ in the sample in which unexpected (periodically decreasing $\mathrm{CO}_{2}$ ) values can be observed. 'Control' does not contain fertilizer, nor added glucose.
'Control+Glucose' contains $0,1 \mathrm{~g}$ of added glucose. 'Biofertilizer' contains Phylazonit bio-fertilizer. 'Biofertilizer+Glucose' contains Phylazonit bio-fertilizer and 0,1 g of added glucose. DOI, 10.5256/ f1000research.12936.d182664 ${ }^{38}$.

\section{Competing interests}

No competing interests were disclosed.

\section{Grant information}

The author(s) declared that no grants were involved in supporting this work.

\section{Acknowledgements}

We are grateful to the Department of Agricultural Chemistry and Soil Sciences at University of Debrecen for providing the experimental setups.
1. Sitkei Gy: Mez"ogazdasági és erdészeti járm"uvek modellezése. Akadémiai Kiadó. 1986; (86).

2. Lauber CL, Strickland MS, Bradford MA, et al: The influence of soil properties on the structure of bacterial and fungal communities across land-use types. Soil Biol Biochem. 2008; 40(9): 2407-2415. Publisher Full Text

3. Ulloa C, Pazmiño K, Cárdenas D, et al:: Desarrollo de repelencia al agua en suelos afectados por incendios, en una zona del parque metropolitano del distrito metropolitano de Quito. La Granja: Journal of Life Sciences. 2014; 19(1): $34-43$.

Publisher Full Text

4. Singla A, Dubey SK, Singh A, et al: Effect of biogas digested slurry-based biochar on methane flux and methanogenic archaeal diversity in paddy soil. Agric Ecosyst Environ. 2014; 197: 278-287.

Publisher Full Text

5. Wardle DA: A comparative assessment of factors which influence microbia biomass carbon and nitrogen levels in soil. Biol Rev. 1992; 67(3): 321-358. Publisher Full Text

6. Olsen RA, Bakken LR: Viability of soil bacteria: Optimization of plate-counting technique and comparison between total counts and plate counts within different size groups. Microb Ecol. 1987; 13(1): 59-74. PubMed Abstract | Publisher Full Text

7. Dick RP: Soil Enzyme Activities as Indicators of Soil Quality. Oregon Agric Exp Stn Journal. 1994; (10): 195.

Reference Source

8. Hanson PJ, Edwards NT, Garten CT, et al:: Separating root and soil microbial contributions to soil respiration: A review of methods and observations. Biogeochemistry. 2000; 48(1): 115-146.

Publisher Full Text

9. Jangid K, Williams MA, Franzluebbers AJ, et al.: Land-use history has a stronger impact on soil microbial community composition than aboveground vegetation and soil properties. Soil Biol Biochem. 2011; 43(10): 2184-2193. Publisher Full Text

10. Cachipuendo-Ulcuango CJ, Requelme N, Gualavisí Cachiguango OM, et al:: Community use of water and land for sustainable production of pasture. La Granja: Journal of Life Sciences. 2017; 26(2): 142-154. Reference Source

11. Granda MJ, Yánez P: Estudio sobre la percepcion de los beneficios del programa socio bosque en la region amazonica ecuatoriana. La Granja: Journal of Life Sciences. 2017; 26(2): 28-37. Publisher Full Text

12. Vineela $\mathrm{C}$, Wani SP, Srinivasarao $\mathrm{CH}$, et al.: Microbial properties of soils as affected by cropping and nutrient management practices in several long-term manurial experiments in the semi-arid tropics of India. Appl Soil Ecol. 2008; 40(1): 165-173.

Publisher Full Text
13. Olivares BO: Description of soil management in agricultural production systems of sector Hammock in Anzoategui, Venezuela. La Granja: Journal of Life Sciences. 2016; 23(1): 14-24. Reference Source

14. El-Yazeid $\mathrm{A}$, Abou-Aly $\mathrm{H}$, Mady $\mathrm{M}$, et al:: Enhancing growth, productivity and quality of squash plants using phosphate dissolving microorganisms (bio phosphor) combined with boron foliar spray. Res J Agr Biol Sci. 2007; 3(4): 274-286.

Reference Source

15. Garg V, Kukreja K, Singla A: Efficacy of native rhizobial strains for nodulation and plant biomass production in berseem (Trifolium alexandrinum $\mathrm{L}$ ) Agriclnternational. 2016; 3(1-2): 89-95. Reference Source

16. Garg V, Kukreja K, Gera R, et al.: Production of indole-3-acetic acid by berseem (Trifolium alexandrinum L.) rhizobia isolated from Haryana, India. Agr Sci Digest. 2015; 35(3): 229-232. Publisher Full Text

17. Anderson $\mathrm{TH}$, Domsch $\mathrm{KH}$ : The metabolic quotient for $\mathrm{CO}_{2}\left(q \mathrm{CO}_{2}\right)$ as a specific activity parameter to assess the effects of environmental conditions, such as ph, on the microbial biomass of forest soils. Soil Biol Biochem. 1993; 25(3): 393-395. Publisher Full Text

18. Allison SD, Czimczik Cl, Treseder KK: Microbial activity and soil respiration under nitrogen addition in Alaskan boreal forest. Glob Chang Biol. 2008; 14(5) 1156-1168.

Publisher Full Text

19. Mátyás $\mathrm{B}$, Kátai J, Horváth J: Comparative analysis of certain soil microbiological characteristics of carbon cycle. Acta Agraria. 2016; (69): 137-142. Reference Source

20. Horváth J, Mátyás B, Kátai J: Impact of agronomic factors on urease enzyme activity in a long term fertilizer experiment. Acta Agraria. 2016; (68): 43-48. Reference Source

21. Mátyás $\mathrm{B}$, Tállai M, Kátai J, et al:: The impact of fertilisation on a few microbiological parameters of the carbon cycle. Acta Agraria. 2015; (64): 45-50. Reference Source

22. Horváth J, Tállai M, Mátyás B: A talaj nitrogéntartalmának és néhány egyéb tulajdonságának változása egytrágyázási tartamkísérletben csernozjom talajon. Acta Agraria. 2015; (64): 39-44.

23. Klimes-Szmik A: A talajok fizikai tulajdonságainak vizsgálata. Talaj és trágyvizsgálati módszerek. 1970; (48): 83-161.

24. Buzás I: Manual of Soil and Agrochemical Analysis. INDA 4231 Kiadó. Budapest, 1988; 1.

25. Stefanovits Talajtan P: Mezogazdasági Kiadó. Budapest, 1975.

26. Oades JM: Associations of Colloids in Soil Aggregates. Soil Colloids and their 
Associations in Aggregates. (Chapter 17) 1990; 214: 463-483. Publisher Full Text

27. Standard: MSZ-08 0205:1978. Hungarian Standards Institution, 1978.

28. Kong $\mathrm{Y}$, Nagano $\mathrm{H}$, Kátai J, et al:: $\mathrm{CO}_{2}, \mathrm{~N}_{2} \mathrm{O}$ and $\mathrm{CH}_{4}$ production/consumption potentials of soils under different land-use types in central Japan and easter Hungary. Soil Science and Plant Nutrition. 2013; 59(3): 455-462. Publisher Full Text

29. Felföldy L: A biológiai vízmin"osítés. Budapest kidadó, 1987; (59): 172-174.

30. Szegi J: Talajmikrobiológiai vizsgálati módszerek. Mezogazdasági Kiadó, Budapest, 1979; 250-256.

Reference Source

31. Székely Á: Talaj-és agrokémiai vizsgálati módszerek 2. Mezogazdasági kiadó, 1988; 115.

32. Vance ED, Brookes PC, Jenkinson DS: An extractionmethod for measuring soil microbial biomass-C. Soil Biol Biochem. 1987; 19(6): 703-707. Publisher Full Text

33. Barreles-Brito E, Etchevers-Barra J, Hidalgo-Moreno C, et al:: Determinación in vitro de la emisión de $\mathrm{CO}_{2}$ en muestras de mantillo in vitro determination of $\mathrm{CO}_{2}$ emission in forest litter. Agrociencia. 2014; 48(7): 679-690. Reference Source
34. Bae SL, Kwak K, Kim S, et al:: Isolation and characterization of $\mathrm{CO}_{2}$-fixing hydrogen-oxidizing marine bacteria. J Biosci Bioeng. 2001; 91(5): $442-8$

PubMed Abstract | Publisher Full Text

35. Singla A, Inubushi $\mathrm{K}: \mathrm{CO}_{2}, \mathrm{CH}_{4}$ and $\mathrm{N}_{2} \mathrm{O}$ production potential of paddy soil after biogas byproducts application under waterlogged condition. Int J Agric Environ Biotech. 2013; 6(2): 233-239. Reference Source

36. Kurek I, Reed JS, Dyson L, et al.: Engineered CO2-Fixing Chemotrophic Microorganisms Producing Carbon-Based Products and Methods of Using the Same. Patent, US20170152533 A1. 2017. Reference Source

37. Bautista G, Mátyás B, Carpio I, et al.: Dataset 1 in: Unexpected results in Chernozem soil respiration while measuring the effect of a bio-fertilizer on soil microbial activity. F1000Research. 2017. Data Source

38. Bautista G, Mátyás B, Carpio I, et al.: Dataset 2 in: Unexpected results in Chernozem soil respiration while measuring the effect of a bio-fertilizer on soil microbial activity. F1000Research. 2017.

Data Source 


\title{
Open Peer Review
}

\section{Current Peer Review Status:}

\section{Version 2}

Reviewer Report 22 December 2017

https://doi.org/10.5256/f1000research.14500.r29290

(C) 2017 Ali M. This is an open access peer review report distributed under the terms of the Creative Commons Attribution License, which permits unrestricted use, distribution, and reproduction in any medium, provided the original work is properly cited.

\section{Muhammad Aslam Ali \\ Department of Environmental Science, Bangladesh Agricultural University, Mymensingh, Bangladesh}

I have read this submission. I believe that I have an appropriate level of expertise to confirm that it is of an acceptable scientific standard to publish as a research note, however in case of a full manuscript it needs more scientific investigation on the variation of soil respiration as well as $\mathrm{CO} 2$ fluxes and soil microbial activities under specified environmental conditions.

Competing Interests: No competing interests were disclosed.

I confirm that I have read this submission and believe that I have an appropriate level of expertise to confirm that it is of an acceptable scientific standard.

\section{Version 1}

Reviewer Report 29 November 2017

https://doi.org/10.5256/f1000research.14027.r27583

(C) 2017 Ali M. This is an open access peer review report distributed under the terms of the Creative Commons Attribution License, which permits unrestricted use, distribution, and reproduction in any medium, provided the original work is properly cited.

\author{
Muhammad Aslam Ali \\ Department of Environmental Science, Bangladesh Agricultural University, Mymensingh, \\ Bangladesh
}

1. Why did the authors select Phylazonit biofertilizer? Does it contain any methanotrophs bacterial 
spp. or any electron acceptors? Didn't find the composition.

2 . Why not investigate the $\mathrm{CO} 2$ production rate with varying levels such as $0.5 \%, 1 \%$ and $5 \%$ substrates application in soils?

2. What were the initial content of organic carbon, total nitrogen, soil $\mathrm{pH}$, redox status (Soil Eh) and microbial composition of the collected 24 soil samples?

3. How did the researchers control the pressure within the glass bottles during the experimental period?

4. How did the authors maintain moisture levels or water filled pore space uniformity in the 24 soil samples containing glass bottles?

5. Why didn't you collect the gas samples evolved from the soils in glass bottles at varying time hours?

6. Why didn't you follow the light/dark conditions in the Incubator where the glass bottles were kept?

7. All the Figures are not clear, no contrasting colors or bullets with lines used to differentiate the treatments.

8. How were soil microbial activities assessed? Methanogens and methanotroph's relative intensity were not found in this script, which are the major focus related to the current research topic.

Is the work clearly and accurately presented and does it cite the current literature? Partly

Is the study design appropriate and is the work technically sound?

Partly

Are sufficient details of methods and analysis provided to allow replication by others? Partly

If applicable, is the statistical analysis and its interpretation appropriate? Partly

Are all the source data underlying the results available to ensure full reproducibility? Partly

Are the conclusions drawn adequately supported by the results? Partly

Competing Interests: No competing interests were disclosed.

Reviewer Expertise: Soil GHGs flux measurement, soil microbes \& environment

I confirm that I have read this submission and believe that I have an appropriate level of expertise to confirm that it is of an acceptable scientific standard, however I have significant reservations, as outlined above.

Author Response 01 Dec 2017

Gabriela Bautista, University of Debrecen, Debrecen, Hungary 
Dear Prof. Muhammad Aslam Ali

We are trying to answer your questions, and submit a second version of the manuscript in order to clarify the following points.

1. Why did the authors select Phylazonit biofertilizer? Does it contain any methanotrophs bacterial spp. or any electron acceptors? Didn't find the composition.

The Phylazonit Ltd. provided the biofertilzer for test.

The Methods chapter begins with the information related to the composition: "Bacillus megaterium, Bacillus circulans, Pseudomonas putida, in an optimized ratio for soil injection". We did not say that the fertilizer contains methanotrophs bacterial spp. or any electron acceptors. Thats why the results presented in the paper are unexpected.

2. Why not investigate the $\mathrm{CO} 2$ production rate with varying levels such as $0.5 \%, 1 \%$ and $\mathbf{5 \%}$ substrates application in soils?

This Research note discusses only unexpected results come from an experiment that was carried out using Oxitop devices. This is part of a project in which more methods are applied. In an other method (using liquid-alkaline absorption) is possible to setup the different levels, but that is not part of the discussion of the present paper. Using Oxitop bottles only one level is possible for the setup.

2. What were the initial content of organic carbon, total nitrogen, soil $\mathrm{pH}$, redox status (Soil Eh) and microbial composition of the collected 24 soil samples?

In the Dataset 1: Average values for a number of different soil properties you can find the main phyical, chemical and microbial soil properties such as $\mathrm{pH}(\mathrm{H} 2 \mathrm{O}), \mathrm{pH}(\mathrm{KCl})$, Organic carbon. We will extend the dataset with the Total Nitrogen in the second version of the paper.

3. How did the researchers control the pressure within the glass bottles during the experimental period?

The Oxitop automatically measures the changes in the bottles due to gas consumption by its sensor, there is no needed to apply external measurement.

4. How did the authors maintain moisture levels or water filled pore space uniformity in the 24 soil samples containing glass bottles?

The measurement was carried out in closed system (bootles), it is not possible to open the bottles during the measurement.

5. Why didn't you collect the gas samples evolved from the soils in glass bottles at 
varying time hours?

The Oxitop continously measures the changes. As Fig. 1 and Fig. 2 show during 168 hours the gas oxygen consumption/ $\mathrm{CO} 2$ production were measured.

6. Why didn't you follow the light/dark conditions in the Incubator where the glass bottles were kept?

In order to avoid the effect of the photosynthesis by algeas. We were interested in soil bacteria activities only.

7. All the Figures are not clear, no contrasting colors or bullets with lines used to differentiate the treatments.

We do not understand this question. In Both figures we used different colors and bullets.

Control (absolute): Blue

Control + glucose: Red

Treated: Green

Treated + glucose: Purple

8. How were soil microbial activities assessed? Methanogens and methanotroph's relative intensity were not found in this script, which are the major focus related to the current research topic.

This paper was submitted as a Research note. Research notes are often preliminary studies, descriptions of unexpected and perhaps unexplained observations or lab protocols. We concluded that "Further genomics research could detect the bacterial strains that consumed the $\mathrm{CO} 2$ in this soil."

\section{Gabriela Bautista, Bence Mátyás}

Competing Interests: No competing interests were disclosed.

Reviewer Report 20 November 2017

https://doi.org/10.5256/f1000research.14027.r27580

(C) 2017 Singla A. This is an open access peer review report distributed under the terms of the Creative Commons Attribution License, which permits unrestricted use, distribution, and reproduction in any medium, provided the original work is properly cited.

\section{Ankit Singla}


Regional Centre of Organic Farming, Bhubaneswar, Odisha, India

Bautista and Matyas observed unexpected results in Chernozem soil respiration following the different fertilizer treatments. I think, the values of Dataset 2 could be directly included in the main content of the paper, if possible. The title of Dataset 1 should be "Average values for various properties of Chernozem soil".

I have answered 'partly' to the question 'Are all the source data underlying the results available to ensure full reproducibility?' as soil ecosystems are very diverse and results could vary under different environmental conditions.

Is the work clearly and accurately presented and does it cite the current literature? Yes

Is the study design appropriate and is the work technically sound?

Yes

Are sufficient details of methods and analysis provided to allow replication by others? Yes

If applicable, is the statistical analysis and its interpretation appropriate?

Yes

Are all the source data underlying the results available to ensure full reproducibility? Partly

Are the conclusions drawn adequately supported by the results?

Yes

Competing Interests: No competing interests were disclosed.

I confirm that I have read this submission and believe that I have an appropriate level of expertise to confirm that it is of an acceptable scientific standard. 
The benefits of publishing with F1000Research:

- Your article is published within days, with no editorial bias

- You can publish traditional articles, null/negative results, case reports, data notes and more

- The peer review process is transparent and collaborative

- Your article is indexed in PubMed after passing peer review

- Dedicated customer support at every stage

For pre-submission enquiries, contact research@f1000.com 